\title{
The Multi-Dimensional Impact Of International Tourism
}

\author{
Hany H. Makhlouf, University of the District of Columbia, USA
}

\begin{abstract}
Most countries - be they developed or developing, rich or poor, and large or small - compete for a larger share of the international tourism dollars. They capitalize on their cultural heritage, historic landmarks, rich wildlife, ancient monuments, scenic beauty, and other distinctive attractions and invest in world class resorts, hotels, and entertainment facilities to increase their appeal to the greatest numbers and different types of international travelers. However, success in international tourism is not without a cost. Aside from the investment needed for developing, upgrading, and maintaining the tourism infrastructure, there are environmental and social costs that need to be measured and carefully managed. Although many economists point to the revenues that are earned by destination countries from international tourism, some observers in developing countries show concern about the creation of a state of economic, political and cultural dependency that may have long-term negative consequences.
\end{abstract}

This article explores the history, present importance, trends, and growth patterns of international tourism. It addresses a number of questions: 1) Has international tourism been a curse or a blessing for countries that have become economically dependent on it?, 2) Have recent trends been more or less favorable to the poorest countries?, 3) What are the forces that bring about shifts and changes in international tourism?, and 4) What are the future prospects for this industry?

Keywords: International Tourism; Tourism; Economic Dependency; Tourism Management; Tourism Code of Ethics; Tourism Revenues; Tourist's Rights and Obligations

\section{INTRODUCTION}

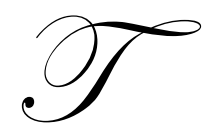

ourism is one of the oldest industries in the world. As far back as 3,000 B.C., some of the elite in Mesopotamia, who had discretionary income, traveled to foreign destinations for leisure. The same happened in ancient Egypt, Greece, and Rome. Wealthy Romans travelled to the sites of older civilizations like the Egyptian and Greek as early as 200 B.C. In the Middle Ages, religious tourism started to grew. However, it was not until the nineteenth century that cultural and recreational tourism became within reach of a larger number of people, particularly in Europe. As Weaver and Lawton (2002) noted, Thomas Cook, who was a British Baptist Priest that turned into a pioneer in international tourism, began a series of Bible camps and other religious excursions in the 1840s. In the 1860s, he shifted his attention to broad-based excursions. His first international excursion was to the Swiss Alps in 1863. This was followed by an around-the-world excursion in 1872. These "Cook excursions (mark) the beginning of international tourism...although such trips were... still the prerogative of the wealthy" (Weaver and Lawton, 2002, p. 66).

At present, international tourism occupies fourth place among the world's leading industries, the other three being energy, chemicals, and automotives (Honey and Gilpin, 2009, p. 2). In 2010, the number of international tourists reached about 940 million, compared to a mere 25 million in 1950. The annual revenue from this industry has also been growing at an annual rate ranging from 4 to 7 percent, and reaching $\$ 919$ billion in 2010, according to the UN World Tourist Organization (WTO). As the number of tourists and the revenues from international tourism grew, the number of favored destination countries had also increased, with the developing and emergent economies attracting increasingly larger numbers of tourists. As Honey and Golpin (2009) pointed out, "In 1950, just 15 
destinations - primarily European - accounted for 98 percent of all international arrivals. By 2007 that figure had fallen to 57 percent...The developing world has now become ... major growth area. Tourism (has become) a key foreign exchange earner for 83 percent of developing countries and the leading export earner for one-third of the world's poorest countries" (p. 2). Despite this trend, international tourism, as an industry, is far below its potential in many developing countries in terms of the dollars earned. Hence, there is room for growth with more investment in the infrastructure and tourism-related businesses and more ambitious tourism management and marketing strategies. Referring to the importance of the strategic leadership role of destination country governments, Honey and Gilpin (2009) noted that "tourism cannot grow into a thriving sector...without constructive leadership from the national government. Too many countries fail to reap the rewards of tourism because of poor planning, poorly thought out strategies, and fragmented policies" (p.9).

\section{What is Tourism?}

The term "tourism" implies different things to different people. WTO (1995) defines it from a broad perspective as the "activities of persons traveling to and staying in places outside their usual environment for not more than one consecutive year for leisure, business or other purposes". Goeldner and Rjichie (2009) offer a twopart definition. The first part refers to it as "the processes, activities, and outcomes arising from the relationships and the interactions among tourists, tourism suppliers, host governments, host communities, and surrounding environments that are involved in the interacting and hosting of visitors" (p. 6). The second part describes it as "the industry of travel, hotels, transportation, and all other components that serve the needs of travelers" (p. 6). This definition explains what tourism is all about from two different perspectives, but combined they complement each other. As Weaver and Lawton (2002) commented, each of the varying definitions of tourism reflects "specific requirements and circumstances" (P. 2), particularly when one takes into account that this industry is fragmented and composed of many diverse businesses that are not exclusively dedicated to serving the needs of international tourists.

Equally challenging to arriving at a universally acceptable definition of tourism is finding a commonly accepted explanation of who constitutes an international tourist. Based on its definition of tourism, WTO (1995) defines tourists as people who "travel to and stay in places outside their usual environment for more than twentyfour (24) hours and not more than one consecutive year for leisure, business, and other purposes not related to the exercise of an activity remunerated from within the place visited" (P 14). Excluded from the definition of a tourist, therefore, is an individual who travels to other locations for employment purposes. From the perspectives of international tourism, OECD defines international tourists as "persons visiting (a) country for less than one year, specifically for purposes of recreation or holiday, medical care, religious observances, family affairs, participation in international sports and cultural events, conferences, and other meetings". This definition not only describes the type of travelers who should be classified as international tourists for statistical purposes, but also the different types or forms of international tourism. A UN publication (1999) further contributes to our understanding of who should be classified as international tourists by pointing to those who should not be counted as such. The groups to be excluded include foreign students, crew members of foreign ships and aircrafts, travelers who stay in a given country for less than one day (like international excursionists), persons in transit to other countries, and employees of international organizations or foreign embassies (p.211).

\section{TOURISM IN THE WORLD ECONOMY}

Tourism has a multi-faceted impact on both the countries of origin and the countries of destination. Such an impact is economic, cultural, environmental, social, educational, and political. As mentioned earlier, international tourism was responsible for the direct infusion of $\$ 919$ billion into the economies of destination countries in 2010, with a potential increase over the next decade that surpasses projections for many other industries. Since most countries in the world are both countries of origin and destination, they share the benefits and costs of international tourism. Therefore, they have a common interest in providing tourists with needed support, legal protection, and services. 


\section{ECONOMIC BENEFITS}

Seen as an invisible export, international tourism is equated with merchandize and service exports in contributing to the destination countries' revenues, employment base, business profits, and economic revitalization in local communities in touristic areas. Table 1 shows international tourism receipts as a percentage of exports in the top 20 countries that are most dependent on this industry.

Table 1: Top 20 Countries Ranked by Percentage of Tourism Receipts as a Percentage of Exports

\begin{tabular}{|l|c|c|}
\hline \multicolumn{1}{|c|}{ Country } & $\begin{array}{c}\text { International Tourism Receipts as a } \\
\text { Percent of Total Exports }\end{array}$ & Last Year Reported \\
\hline The Bahamas & $65 \%$ & 2009 \\
\hline Samoa & $63 \%$ & 2005 \\
\hline Cape Verde & $60 \%$ & 2005 \\
\hline French Polynesia & $59 \%$ & 2009 \\
\hline Albania & $58 \%$ & 2004 \\
\hline Madagascar & $52 \%$ & 2009 \\
\hline Jamaica & $51 \%$ & 2005 \\
\hline Barbados & $49 \%$ & 2995 \\
\hline Comoros & $49 \%$ & 2009 \\
\hline Fiji & $46 \%$ & 2009 \\
\hline Croatia & $41 \%$ & 2000 \\
\hline Eritrea & $37 \%$ & 2009 \\
\hline Seychelles & $36 \%$ & 2009 \\
\hline Belize & $35 \%$ & 2009 \\
\hline Mauritius & $33 \%$ & 2009 \\
\hline Morocco & $30 \%$ & 2009 \\
\hline Lebanon & $27 \%$ & 2009 \\
\hline Gambia & $23 \%$ & 2009 \\
\hline Tanzania & $23 \%$ & 2009 \\
\hline Cyprus & $21 \%$ & \\
\hline Sour & & \\
\hline
\end{tabular}

Sources: World Development Indicator Database, and World Tourism Organization Yearbook of Tourism Statistics, 2010

This table reflects the extent of those countries' dependence on international tourism receipts, which range from $65 \%$ of total exports in the case of the Bahamas to $21 \%$ in the case of Cyprus. Despite such dependence on this economic sector, such a group of tourism-oriented economies in Table 1 are not the largest recipients of tourism dollars. This distinction is earned by larger countries, such as those included in Table 2, to which international tourism revenues are small relative to the sizes of their economies and total export earnings.

Table 2: Top International Tourism Dollar Recipients

\begin{tabular}{|c|c|c|}
\hline Country & Dollar Receipts & Percent of Total Exports \\
\hline United States & \$122.94 Billion & $9 \%(2009)$ \\
\hline Spain & $\$ 52.96$ Billion & $18 \%(2009)$ \\
\hline United Kingdom & \$39.57 Billion & $6 \%(2009)$ \\
\hline Germany & \$38.38 Billion & $3 \%(2009)$ \\
\hline Italy & \$ 38.26 Billion & $8 \%(2009)$ \\
\hline France & \$32.09 Billion & $9 \%(2009)$ \\
\hline China & \$31.84 Billion & $3 \%(2009)$ \\
\hline Australia & $\$ 20.68$ Billion & $12 \%(2008)$ \\
\hline Austria & \$19.31 Billion & $11 \%(2009)$ \\
\hline Canada & \$15.38 Billlion & $4 \%(2009)$ \\
\hline
\end{tabular}

Sources: World Development Indicators Database; and World Tourism Organization Yearbook of Tourism Statistics (2010) 
The returns on the destination countries' investment in their tourism sectors are usually measured in terms of their net contribution to trade and payment balances; job creation; profits realized by tourism connected businesses, such as hotels, restaurants, local transportation companies, resorts, and entertainment establishments; and national and local governments' tax revenues. Those countries also calculate the multiplier effect of expenditures made by tourists when they buy locally-made products and services as noted by Padure and Turtureanu (2005):

Tourist spending multiplies as it passes through various sections of the economy. Tourist expenditures not only support the tourist industry directly, but also help indirectly to support many other industries. In this way, money spent by tourists is actually used several times and spreads into various sectors of the economy. (p.4)

This means that every time money passes from one hand or one business to the next, it acts as a stimulus, thus multiplying the impact and value of tourist expenditures. The multiplier is also seen in increased employment beyond the tourism sector in such industries as furniture, construction, food and beverage production, souvenirs and gifts, handicrafts, and clothing. Another indirect benefit that has a broader impact on residents at destination countries comes with the building of a modern tourism infrastructure from improved road networks and airports to museums, amusement parks, health care facilities and world class hotels and resorts that have a positive impact on the quality of life in local communities. Such infrastructural facilities are not reserved for the exclusive use of foreign visitors and can be economically, socially, and culturally enriching for local residents.

\section{THE DANGER OF ECONOMIC DEPENDENCY}

As stated earlier, tourism is the fourth largest industry in the word. It is responsible for 10 percent of the world's income and about the same percentage of jobs. However, the level of dependency on this industry in different countries and regions is not the same. Smaller countries, like the Bahamas that have emphasized this industry and invested heavily in it, find themselves economically too dependent on it and largely defenseless against the negative external developments like global recessions that affect the flow of tourists. For the Bahamas - an extreme example of dependency - international tourism accounts for 60 percent of the gross national product and about 50 percent of employment. As a result, the recession that began in the United States in the second half of 2008, spread to other countries and resulted in an overall 4 percent drop in global tourism revenues, and the number of tourists visiting the Bahamas dropped by 112,000, which is a significant number for such a small country (Travel Documents System, 2009).

Such a reduction in the number of tourists resulted in more than a drop in revenues and tourism-related jobs. It meant temporary delay in re-paying the debt incurred to build and continue to modernize the tourism infrastructure and a loss to foreign investors (such as international hotels) in such an important sector. As Gmelch (2003) observed about the Caribbean islands, in general, building hotels, resorts, airports, roads, and other modern facilities that would attract international tourists required large-scale borrowing and the investment of multinational hotels and financial institutions. "Two- thirds of the hotel rooms in that region are foreign owned and the tour companies that arrange visitors' activities are often foreign owned", according to Gmelch (2003). The conclusion to be drawn from the Caribbean islands' experience is that the smaller and the less diversified the economies of destination countries, the greater their dependence on tourism revenues and tourism-related jobs and the more economically vulnerable they would become as a result of uncontrollable external forces and trends. It addition, dependence on foreign investment in tourism reduces the net benefits realized due to "leakages", such as the profits repatriated by international hotels and the payments made for tourism-related imports.

\section{SOCIO-CULTURAL IMPACT}

International tourism makes possible the interaction of people from different cultures in a relaxed, friendly, and non-confrontational environment. As a result, tourists would leave the host country with a greater understanding of its culture, history, and way of life that may help in erasing some of the negative stereotypes that are based more on falsehoods than realities. Similarly, the host society would have a more realistic view of the differences and similarities among people with different cultural backgrounds. This could leave us with the conclusion that the cultural impact of international tourism could be quite positive, at least in terms of global peopleto-people relations. 
Some critics of international tourism in smaller and developing countries, however, warn not only of the development of a state of economic dependency, but also of the emergence of both cultural and political dependencies that limit those countries' policy options and cloud their individuality and cultural identity. Fears are expressed that tourism could eventually lead to, or at least contribute to, the destruction of indigenous cultures in countries that become too dependent on it, and a significant percentage of whose citizens become too exposed to foreign cultures and moral values. Indigenous cultures may be viewed as backward or less modern, particularly by individuals and groups whose livelihoods are tied to the tourism industry, much to the disappointment of cultural purists in those societies. Exposure to many foreign cultures is sometimes blamed for making tourism industry employees too pluralistic in their outlook and culturally neutral. The outcome could be socio-cultural polarization and conflict between the traditionalists who resent change in indigenous cultures and modernists who see the merits of change.

\section{ROLE OF DESTINATION COUNTRY GOVERNMENTS}

Governments of destination countries have a major role to play in the development, management, and promotion of international tourism. They take responsibility for developing, modernizing and managing the tourism infrastructure, such as airports, roads, and national parks, and establishing the regulatory systems that prevent uncontrollable growth that may damage the environment, historic sites and monuments. In addition, governments are supposed to act to make it possible for tourists to leave the destination countries with favorable opinions by planning to avoid the bottlenecks that disrupt the tourists' plans and schedules. For example, if airports, air flights, or roads are too inadequate to meet tourist demand, those affected would be stranded and may never consider repeat visits to such a destination.

Governments also have a primary responsibility in ensuring fair treatment of tourists as well as protecting their and their property's safety. In 1999, the United Nations General Assembly recognized a code of ethics developed by the World Tourism Organization that urged equal and ethical treatment of international tourists. Article 1, paragraph 4 of those codes states that:

It is the task of the public authorities to provide protection for tourists and visitors and their belongings. They must pay particular attention to the safety of foreign tourists owing to the particular vulnerability they may have. They should facilitate the introduction of specific means of information, prevention, security, insurance and assistance consistent with their needs. Any attacks, assault, kidnappings or threats against tourists or workers in the tourism industry, as well as the willful destruction of tourism facilities or of elements of cultural or natural heritage, should be severely condemned and punished in accordance with their respective national laws.

These codes have also emphasized respect for the host countries' traditions and the protection of their national heritage, including bio-diversity and ecosystems in planning the tourism infrastructure. Furthermore, they refer to the responsibility of tourists to abide by the host countries' laws and abstain from intentionally engaging in offensive conduct, including criminal acts that injure the local population or damage the local environment.

\section{TRENDS IN INTERNATIONAL TOURISM}

International tourism has been growing at rates ranging from 4 to 7 percent annually. It recovered before other industries after the great recession of 2008-2009. By 2020, the number of international tourists, which reached 940 million in 2010, is expected to rise to 1.6 billion by 2020, according to the World Tourism Organization (UNWTO, 2005, p.1). Among the changes in this industry that are likely to continue is the shift in desirable tourist destinations from traditional sites in Europe and America to the developing and emerging countries, such as China and other countries in East Asia and the Pacific. Table 3 shows projected growth by region between 1995 and 2020. 
Table 3: Growth in Tourist Destinations by Region

\begin{tabular}{|l|c|}
\hline \multicolumn{1}{|c|}{ Region } & Annual Rate of Growth (1995-2020) \\
\hline Africa & $5.5 \%$ \\
\hline The Americas & $3.8 \%$ \\
\hline East Asia and the Pacific & $6.5 \%$ \\
\hline Europe & $3.1 \%$ \\
\hline The Middle East & $6.7 \%$ \\
\hline South Asia & $6.2 \%$ \\
\hline World Average & $4.1 \%$ \\
\hline
\end{tabular}

Source: Word Tourism Organization Tourism Directly

Due to the lead that traditional European destination countries have maintained since the emergence of international tourism, those sites would continue to have a major share of international arrivals despite the changes shown in Table 3. As the projections of the World Tourism Organization indicate, "Europe will maintain the highest share of world arrivals, although there will be a decline from 60 percent in 1995 to 46 percent in 2020" (UNWTO's Tourism 2020 vision, p. 2).

In addition to the geographic shifts in tourists' destinations, there is a notable change in the type of tourism emphasized by new destination countries. Mauritius, for example, has developed the infrastructure needed for medical tourism - the type of tourism that was traditionally exclusively associated with Europe and North America. Other countries that have also achieved success in this type of tourism include Thailand, Brazil, Tunisia, and Morocco (Ackbarally, 2011, pp.68-69).

\section{CONCLUSION}

Tourism is one of the largest industries in the world. It contributes to the destination countries' gross national product, employment base, economic vigor, government tax revenues, and positive global image. However, it is an industry that is sensitive to negative external forces and events, such as global economic recessions and foreign policy disputes, as well as internal developments, such as civil wars, security issues, epidemics, and political instability. In the case of small destination countries, it may create a state of political, social and/or economic dependency that has the potential of limiting their public policy options and freedom of action in international forums. In addition, the revenues realized are not without some direct and indirect costs that reduce the net benefits received. Included among those costs are payments for the import of goods and services particularly needed by foreign visitors, remittances of profits realized by international hotel chains, possible environmental degradation (particularly in the case of mega-resorts that may increase pollution and negatively impact wildlife), and the risk of a general increase in prices due to the increase in demand for products and services in domestic markets. Despite such costs and risks, the overall benefits are usually attractive enough over the long range to cause most nations, regardless of their sizes and per capita incomes, to compete for larger shares of tourist dollars and the number of arrivals.

Maximizing long-term benefits from international tourism as a sector of destination country economies requires the adoption of balanced investment and management approach. A balanced strategy by destination countries should aim at increasing revenues and competitiveness and, in the meantime, minimizing possible environmental damage, as well as perceived undesirable political, social, and cultural outcomes. In addition, sustainable growth in this industry requires strict adherence to recognized codes of ethics according to which international tourists' rights, personal safety and property are to receive reasonable protection by host country authorities.

\section{AUTHOR INFORMATION}

Hany H. Makhlouf is a professor of management and international business; and chairman of the Department of Management, Marketing, and Information System at the University of the District of Columbia. He has authored 43 papers and articles in international management, international marketing, entrepreneurship, and strategic management. His most recent articles focused on sovereign wealth funds, international entrepreneurship, social 
entrepreneurship from a global perspective, and entrepreneurship in India and China. He is the co-author of Entrepreneurship: Launching and Managing New Ventures (2007). He has earned a doctorate in international business from the American University in Washington, M.S. in Management from the University of Rhode Island, and a B.A. in Business and Economics from the American University in Cairo. E-mail: hmakhlouf@udc.edu.

\section{REFERENCES}

1. Ackbarally, N. ( 2011, July). Tenfold Increase in Medical Tourism. African Business, 68-69.

2. Cetron, M., De Micco, F., and Davies, O. (2010). Hospitality 2015, the Future of Hospitality and Travel. Lansing, Michigan: the American Hotel and Lodging Educational Institute.

3. Global Codes of Ethics for Tourism (1999). Retrieved from http://www.gdrc.org/unem/ecotour/principles.html.

4. Goeldner, C. and Ritchi, J. (2009). Tourism: Principles, Practices, Philosophies. $11^{\text {th }}$ Edition, Hoboken, New Jersey: John Wiley and Sons

5. Gmelch, G. (2003). Behind the Smile: The Working Lives of Caribbean Tourism. Bloomington, IN: UP.

6. Honey, M. and Gilpin, I. (2009). Tourism in the Developing World, Special Report. Washington, D.C.: The United States Institute of Peace.

7. Nation Master (2011). Economy Statistics>International Tourism, Rceipts> Current US\$ (most recent Z) by Country. Retrieved from http://www.nationmaster.com/graph/eco int tou_rec cur_us internationaltourism-receipts- $7 / 1 / 2011$.

8. $\quad$ OECD (2006). Glossary of Statistical Terms. Retrieved from http://stats.oecd.org/glossary/detail.asp?ID $=5878$.

9. Padure, G., and Turtureanu, I.A. (2005). Economic Impact of Tourism. ACTA Universitatis Danubius Econmica.

10. Travel Documents Systems (2009). Bahamas. Retrieved from http://www.traveldocs.com/bs/economy.htm.

11. United Nations (1999). Handbook of Input-Output Table Compilation and Analysis. Study In Methods: Handbook of National Accounts. Series F. No. 74. New York, NY.

12. UNWTO (1995). Technical Manual: Collection of Tourism Expenditures Statistics Retrieved from http://pub.unwto.org/webRoot/store/shops/Infoshop/Products/1034/ 1034-1.pdf.

13. UNWTO (2005-2010). Tourism 2020 Vision. Retrieved from http://www.directorytourism.com/articles_28-tourism-2020-Vision-html. 6/3/2011.

14. UNWTO (2011). International Tourism 2010:Multi-Speed Recovery. Retrieved from http://www.hotelchange.com/article51501International_Tourism_ Multi_Speed_Reco... 6/5/2011.

15. Weaver, D. and Lawton, 1. (2002). Tourism Management $.2^{\text {nd }}$ Edition. Sydney, Australia: John Wiley \& Sons.

16. World Bank, IMF, and the World Tourism Organization. Yearbook of Tourism Statistics. Retrieved from http://www.worldbank.org/Indicator/ST.INT.RCPT.xp.25. 


\section{NOTES}

